International Journal of Instruction e-ISSN: 1308-1470 • www.e-iji.net

Article submission code: 20210308050221

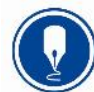

January $2022 \bullet$ Vol.15, No.1

p-ISSN: 1694-609X

pp. $857-872$

Received: 08/03/2021

Revision: 14/08/2021
Accepted: 08/09/2021

OnlineFirst: 05/12/2021

\title{
Effects of Mediation of Learning Interest in Improving Student Learning Achievement
}

\section{Arief Tukiman Hendrawijaya}

Prof., Faculty of Teacher Training and Education, University of Jember, Jember, East Java, Indonesia, hendrawijayapls.fkip@unej.ac.id

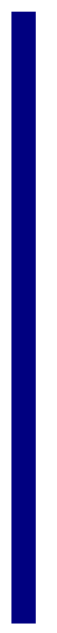

\begin{abstract}
This study aims; to analyze and examine the effects of education level, years of service, work motivation, and work discipline on learning interest; to analyze and examine the effects of education level, years of service, work motivation, work discipline, and learning interest on learning achievement; to analyze and explore the indirect effects of education level, years of service, work motivation, and work discipline on learning achievement mediated by learning interest. This research is an explanatory study, which involved samples of tutors of Packet C Study Group, Jember Regency, in total of 200 respondents. The research data were primary data obtained by online questionnaires, observation, and documentation. The analytical tool used was path analysis to determine the direct effect and indirect effect using SEM method. The results of this study found that education level, years of service, work motivation, and work discipline had a significant positive effect on learning interest. Education level, years of service, work motivation, work discipline, and learning interest had a significant positive effect on learning achievement. Learning interest was able to mediate the effects of education level, years of service, work motivation, and work discipline on learning achievement.
\end{abstract}

Keywords: education level, years of service, work motivation, work discipline, learning interest, learning achievement

\section{INTRODUCTION}

Human resources with excellent competencies can support the success of development to make them valuable. In terms of organizational strategy, an organization can be successful if it has a sustainable competitive advantage. By gaining an advantage, it will encourage human resources in the organization to get a position, which is a major component, more than that any other organization sees (Allameh et al., 2014). The contribution of human resources to an organization is very important since they are very valuable and serve as the backbone of the organization. In education, teacher is a major resource that may be strategically positioned for an organization to achieve excellence. A special and valuable resource is confirmed to create an advantage. Studies show that organization can increase and maintain excellence through the management of special

Citation: Hendrawijaya, A. T. (2022). Effects of mediation of learning interest in improving student learning achievement. International Journal of Instruction, 15(1), 857-872. https://doi.org/10.29333/iji.2022.15149a 
human resources (Khan, 2010; Mutiarawati; 2021). Therefore, this study was conducted to select the results of human resource management practices on employee performance in public sector.

Quality human resources must be improved continuously in line with advances in science and technology. Therefore, the ability of teachers in understanding technology is one of the indicators that the development of teacher skills has been sustainable. The era of digital literacy requires teachers to attend intensive training in accordance with their field of science (Dessler, 2010).

Becker et al. (2001) argue that investment in human resources aims to provide benefits to the organization in the short and long term. By skills and abilities owned, employees will be motivated to continue learning to build a superior business environment. Human resources are used significantly as a driver of other resources and have a strategic position that contributes to realizing company organizational performance with a competitive advantage (Wright et al., 2005).

One of the main foundations of a nation to create a generation capable of competing in the globalization era is education. Education is one way to obtain knowledge, which later can shape human resources. A nation can measure the quality of its human resources in terms of their superiority. Thus, every nation strives to be able to improve the quality of its human resources that can be used to support the success of national development. Education contributes in preparing quality human resources that later will be able to compete in the globalization era.

The dominant and the most important factor in education is the teacher. Teachers are those who can serve as an example and even become self-identification. Quality of learning can be improved through teacher performance assessment (de la Torre, 2020). Teacher's motivation in using technology greatly affects the quality of technology-based learning (Backfish et al., 2021). Quality of teachers needs to be improved by improving the quality of education infrastructure (Kawuryan et al., 2021). High-quality teachers are known through competency tests and it can improve students' learning achievements (Elacqua et al., 2021; Anantadjaya, 2020). Professional teachers have a positive attitude towards their work (Citradin et al., 2019). Therefore, they should have reliable behavior and competencies to develop students as a whole. Currently, teachers are considered a profession that is equal to other professions, so that teachers are required to be professional in carrying out their duties. Professional teachers have a number of competencies that can support their duties and can create a comfortable and optimal atmosphere in learning to foster positive student perceptions. Positive perception will foster students' learning interest.

Teachers as the spearhead of education directly try to influence, foster, and develop students' abilities to become intelligent, skilled and highly moral people. Teacher's low performance is due to the low participation of teachers to participate in seminars and training activities (Ikhsan et al., 2017). In carrying out their duties, teachers are demanded to be able to master their competencies reflected in the ten teacher 
competencies which are the basic abilities that must be possessed by an educator or teacher.

The problems of teacher's education level, years of service, work motivation, and work discipline in relation to student learning interest in improving student learning achievement is an interesting subject to study and research. Based on these descriptions, it is interested to study and analyze the effect of education level, years of service, work motivation, and work discipline on student achievement either directly or mediated by student learning interest.

\section{Literature Review and Hypothesis Development}

Relationship between Education Level, Years of Service, Work Motivation, and Work Discipline and Learning Interest

Learning interest is a special attention given to a particular subject, which is created by willingness and depends on the talents and environment. Interest can be said to be a strong impetus for a person to do everything in order to achieve the goals and ideals that he desires (Silvia, 2001). Generating learning interest is one of teacher's duties. Each teacher must meet the criteria in terms of qualifications and competencies as evidenced by professional certification, meaning that teachers in each education unit must meet academic qualifications with the relevant scientific fields and fields of study or subjects taught in schools, so that they are called competent for their field of work. Teachers must have the minimum level of education before carrying out their duties as professional educators and as a requirement to take a competency test and obtain a professional educator certificate (Ritiauw, 2011).

Years of service is defined as a period of time in which a person is actively involved in a company and reflects employee's loyalty in an institution where he works. A longer years of service will make someone perform better and more reliable (Marisa and Sonia, 2005). The results of research by Ekpe and Mat (2012) show that education has a significant positive effect on learning interest in Nigeria. This study does not support the findings of research by Ibru (2009) and Salman (2009) which confirm that education is related to interest. Other findings include Ajzen (1991), Shane (2003), Gatewood et al. (2004) and Carter and Shaw (2006) found that education is positively related to interest.

The hypotheses proposed based on some of the descriptions above are:

$\mathrm{H}_{1}$ : Tutor's level of education has a positive effect on learning interest.

$\mathrm{H}_{2}$ : Tutor's years of service has a positive effect on learning interest.

$\mathrm{H}_{3}$ : Tutor's work motivation has a positive effect on learning interest.

$\mathrm{H}_{4}$ : Tutor's work discipline has a positive effect on learning interest. 


\section{The Relationship between Education Level, Years of Service, Work Motivation, Work Discipline, and Learning interestand Learning Interest}

Learning achievement is influenced by student learning motivation where the driving factor is participation in classroom learning. Motivation can also be said to be a series of efforts to provide certain conditions, so that someone continuously wants to do something and if he does not like it then he will try to get rid of or avoid the feeling of dislike. Motivation is one of the psychological factors that greatly affect someone in carrying out an activity. Someone who performs an activity, such as learning activities to succeed with the goals to be achieved, needs to pay attention and always develops his motivation so that his goals and expectations can be fulfilled. Learning achievement is influenced by motivation from both student's internal and external factors so that they become the focus of achieving learning achievement.

According to Benson et al. (2004), education is an indicator of a person's levels of skill or productivity and is often used as a prerequisite for making decisions. In company, where employees with higher education contribute less to organizational effectiveness than educated workers, it is not possible to achieve higher costs for staff with highly educated workers. Many organizations subsidize current employees to earn bachelor's or advanced degrees (Benson et al., 2004) but do not appraise short-term returns or long-term returns on those investments.

A number of studies show the relationship between education level, years of service, work motivation, work discipline, and learning interest and learning achievement. Van Vugt (2006) found evidence of a relationship between years of service and achievement in professions that require special knowledge and experience. Another study carried out by Fenster (2014) on the relationship between teacher's years of service and student's achievement found that the relationship between teacher's years of service and student's achievement, but other studies (Phillips, 2009) did not find a relationship between years of service and student's achievement.

Other researchers have proven that teachers have a considerable influence on students' achievement. This is consistent with what Coleman, Bradley, Mayer and Mc Lanahan state that, apart from family income, high parental attention and efforts towards their children's education help improve children's academic achievement (Tsui, 2005). Schenider and Coleman also point out the same thing that the direct interest and attention of parents towards children's performance in school is also an important indicator for children's success in school (Kraaykamp. 2000). The family as an informal educational institution is the first and foremost educational environment. Parents in family have an influence on their children's learning achievement (Houtenville and Conway, 2007).

The results of the research by Simba et al. (2016) found that discipline has a moderate positive relationship and explains the variance in academic performance of eighth graders in public primary schools in Muhoroni Sub-County, Kenya. This implies that academic achievement among students increases along with increasing levels of 
discipline. Adejumobi and Ojikutu (2013) found a positive and significant relationship between motivation and achievement. Meanwhile, Zameer et al. (2014) and Manzoor (2011) found a relationship between motivation and achievement. In addition to the relationship between motivation and performance, motivation affects achievement (Diab and Ajlouni, 2012). Obicci (2015), who conducted research in Uganda, found that leadership motivation is a determinant of employee's achievement.

The hypotheses proposed based on some of the descriptions above are:

$\mathrm{H}_{5}$ : Tutor's level of education has a positive effect on learning achievement.

$\mathrm{H}_{6}$ : Tutor's years of service has a positive effect on learning achievement.

$\mathrm{H}_{7}$ : Tutor's work motivation has positive effect on learning achievement.

$\mathrm{H}_{8} \quad$ : Tutor's work discipline has a positive effect on learning achievement.

$\mathrm{H}_{9}$ : Learning interest has a positive effect on learning achievement.

Relationship between Education Level, Years of service, Work Motivation, Work Discipline and Learning Achievement Mediated by Learning Interest

Learning interest can relate to the power of movement that encourages us to face or deal with people, objects, or any activity that can be an effective experience stimulated by activities itself. Interest can be the reason why individuals are involved in an activity, with a sense of wanting to do so that there is a growing urge in the individual to do something that is of his interest and to be involved in an activity. Interest can be concluded as an impetus in an individual which is based on a sense of liking and interest in a thing or activity and encourages the individual to show behavior. Interest is closely related to motivation, motive and emotional reaction (Crow and Crow, 1992).

According to Carter and Wojtkiewicz (2000), good education is the process of developing one's skills in the form of attitudes and behaviors that prevail in society. Learning achievement has a relationship with parents' education; it has a positive impact on students, their families and the surrounding community. The different parents' levels of education from those who do not complete primary school, graduate from elementary school, junior high school, high school and college also affect student's achievement. Parents who have a high level of education usually have high aspirations for their children's education. They want their children's education to be higher or at least equal to that of their parents. Muola (2010) found a low correlation between parents' involvement or encouragement and academic achievement. Researchers explain that the nature of the encouragement given to children by their parents is important as far as academic achievement is concerned. Parents who put pressure on their children by making too high demands can create anxiety and fear of failure in them rather than providing an effective morale to do well in academic work (Muola, 2010). 
The hypotheses proposed based on some of the descriptions above are:

$\mathrm{H}_{10}$ : Tutor's level of education has a positive effect on learning achievement mediated by learning interest.

$\mathrm{H}_{11}$ : Tutor's years of service has a positive effect on learning achievement mediated by learning interest.

$\mathrm{H}_{12}$ : Tutor's work motivation has a positive effect on learning achievement mediated by learning interest.

$\mathrm{H}_{13}$ : Tutor's work discipline has a positive effect on learning achievement mediated by learning interest.

\section{METHOD}

Tutor is a term for a teacher used in out-of-school education, while learning citizen is a term for students in out-of-school education. These terms will be used in the research results and discussion The population of this study was tutors in Jember Regency, in total of 1,557 tutors. The inclusion criteria of this study were tutors for the Packet C Study Group (Senior High School level) in Jember Regency. The sampling technique used random sampling based on inclusion criteria and set a sample of 200 respondents. The main data in the study used primary data collected by observation and online questionnaires. Data collection by questionnaires was carried out from September 2020. The results of the instrument validity test on the variables of education level, years of service, work motivation, work discipline, learning interest, learning achievement indicated a correlation coefficient from 0.445 to 0.627 with a significance value between 0.000 , thus indicating a significance value of less than $\alpha(0.05)$. It means all items in variable are valid. Instrument reliability testing obtained Cronbach's Alpha coefficient values ranging from $0.601-0.652$ and greater than 0.60 , therefore the variable instruments are declared reliable (Hair et al., 2010).

Data analysis used path analysis is assisted by AMOS program aimed at knowing the direct and indirect effects of exogenous variables (education level, years of service, work motivation, work discipline) on endogenous variables (learning interest and learning achievement). According to Baron and Kenny (1986), path analysis is used because its superiority can test direct and indirect effects with mediating variables (learning interest).

\section{FINDINGS}

\section{Respondent Data}

The samples were 200 respondents consisting of tutors for Packet C Study Group (Senior High School level) in Jember Regency. Respondent characteristic data included gender, age, latest education and years of service. An overview of each of these characteristics is presented in Table1. 
Table 1

Demographic data of respondents

\begin{tabular}{llll}
\hline \multirow{2}{*}{ Demography } & \multirow{2}{*}{ Description } & Distribution & \\
\cline { 3 - 4 } & & Frequency & Percentage (\%) \\
\hline Gender & Male & 69 & 34.5 \\
\hline Age & Female & 131 & 65.5 \\
\hline & 25-35 years & 82 & 41.0 \\
\hline & $36-45$ years & 94 & 47.0 \\
\hline Latest education & 46-60 years & 24 & 12.0 \\
\hline & Senior High School & 36 & 18.0 \\
\hline & Diploma & 105 & 52.5 \\
\hline Years of service & Bachelor Degree & 50 & 25.0 \\
\hline & Master S2 & 9 & 4.5 \\
\hline & <1 year & 15 & 7.5 \\
\hline & 1-5 years & 59 & 29.5 \\
\hline Total & 6-10 years & 53 & 26.5 \\
\hline
\end{tabular}

The general description of the respondents shows that most of the research respondents are female $(65.5 \%)$, aged between 36-45 years (47.0\%), have the latest diploma level education $(52.5 \%)$ and already have more than 10 years of work experience $(36.5 \%)$.

\section{Path Analysis}

The direct effect of variables of levels of education, years of work motivation, and work discipline against learning interest and variables of levels of education, years of service, work motivation, work discipline, and learning interest to learning achievement are presented in Table 2.

Table 2

Hypothesis testing direct effect

\begin{tabular}{llccl}
\hline Hypotheses & Regression Model & $\begin{array}{l}\text { Direct } \\
\text { Effect }\end{array}$ & $\begin{array}{l}\text { Critical } \\
\text { Ratio }\end{array}$ & Sig. \\
\hline $\mathrm{H}_{1}$ & Education level $\left(\mathrm{X}_{1}\right) \rightarrow$ Learning interest $(\mathrm{Z})$ & .215 & 2.339 & $0.019^{* *}$ \\
\hline $\mathrm{H}_{2}$ & Years of service $\left(\mathrm{X}_{2}\right) \rightarrow$ Learning interest $(\mathrm{Z})$ & 0.184 & 2.122 & $0.034^{*}$ \\
\hline $\mathrm{H}_{3}$ & Work motivation $\left(\mathrm{X}_{3}\right) \rightarrow$ Learning interest $(\mathrm{Z})$ & 0.161 & 2.166 & $0.030^{*}$ \\
\hline $\mathrm{H}_{4}$ & Work discipline $\left(\mathrm{X}_{4}\right) \rightarrow$ Learning interest $(\mathrm{Z})$ & 0.230 & 3.130 & $0.002^{* *}$ \\
\hline $\mathrm{H}_{5}$ & Qualification $\left(\mathrm{X}_{1}\right) \rightarrow$ Learning achievement $(\mathrm{Y})$ & 0.391 & 4.665 & $0.000^{* *}$ \\
\hline $\mathrm{H}_{6}$ & $\begin{array}{c}\text { Years of service }\left(\mathrm{X}_{2}\right) \rightarrow \text { Learning achievement } \\
(\mathrm{Y})\end{array}$ & 0.229 & 2.894 & $0.004^{* *}$ \\
\hline $\mathrm{H}_{7}$ & Motivation $\left(\mathrm{X}_{3}\right) \rightarrow$ The learning achievement $(\mathrm{Y})$ & 0.149 & 2.211 & $0.027^{*}$ \\
\hline $\mathrm{H}_{8}$ & $\begin{array}{c}\text { Work discipline }(\mathrm{X} 4) \rightarrow \text { Learning achievement } \\
(\mathrm{Y})\end{array}$ & 0.156 & 2.306 & $0.021^{*}$ \\
\hline $\mathrm{H}_{9}$ & $\begin{array}{c}\text { Learning interest }(\mathrm{Z}) \rightarrow \text { Learning achievement } \\
(\mathrm{Y})\end{array}$ & 0.139 & 2.184 & $0.029 *$ \\
\hline
\end{tabular}

Note: $* *$ and $*$ are significant at $\alpha=1 \%$ and $5 \%$ 
Table 2 shows that the test results of the direct effect on all variables have a positive coefficient which means that each increase on exogenous variables (education level, years of service, work motivation, and work discipline) will be followed by an increase in endogenous variables (learning interest and learning achievement). The results of statistical testing of the effect of mediation (indirect) on learning interest at education level, years of service, work motivation, and work discipline on learning achievement can be seen in Table 3.

Table 3

Hypotheses testing of indirect effects

\begin{tabular}{lllll}
\hline Hypotheses & Regression Model & $\begin{array}{l}\text { Indirect } \\
\text { Effect }\end{array}$ & $\begin{array}{l}\text { Critical } \\
\text { Ratio }\end{array}$ & Sig. \\
\hline $\mathrm{H}_{10}$ & $\begin{array}{c}\text { Education level }\left(\mathrm{X}_{1}\right) \rightarrow \text { Learning interest } \\
(\mathrm{Z}) \rightarrow \text { Learning achievement }(\mathrm{Y})\end{array}$ & 0.030 & 2.260 & $0.026^{*}$ \\
\hline $\mathrm{H}_{11}$ & $\begin{array}{c}\text { Years of service }\left(\mathrm{X}_{2}\right) \rightarrow \text { Learning interest } \\
(\mathrm{Z}) \rightarrow \text { Learning achievement }(\mathrm{Y})\end{array}$ & 0.026 & 2.055 & $0.043^{*}$ \\
\hline $\mathrm{H}_{12}$ & $\begin{array}{c}\text { Work motivation }\left(\mathrm{X}_{3}\right) \rightarrow \text { Learning } \\
\text { interest }(\mathrm{Z}) \rightarrow \text { Learning achievement } \\
(\mathrm{Y})\end{array}$ & 0.022 & 2.112 & $0.037 *$ \\
\hline $\mathrm{H}_{13}$ & $\begin{array}{c}\text { Work discipline }\left(\mathrm{X}_{4}\right) \rightarrow \text { Learning interest } \\
(\mathrm{Z}) \rightarrow \text { Learning achievement }(\mathrm{Y})\end{array}$ & 0.032 & 2.944 & $0.004^{* *}$ \\
\hline
\end{tabular}

Description: * significant at $\alpha=5 \%$.

The results of hypothesis testing on the indirect influence pathway show that all indirect pathways have a significant effect, which means that learning interest is able to mediate the effect of education level, years of service, work motivation, and work discipline on learning achievement. The recapitulation of the results of testing of the direct effect, indirect effect, and total effect of exogenous variables (education level, years of service, work motivation, and work discipline) on endogenous variables (learning interest and learning achievement) can be seen in Table 4 .

Table 4

Direct, indirect and total

\begin{tabular}{lccc}
\hline Regression Model & $\begin{array}{c}\text { Direct } \\
\text { Effect }\end{array}$ & $\begin{array}{c}\text { Indirect } \\
\text { Effect }\end{array}$ & $\begin{array}{c}\text { Total } \\
\text { Effect }\end{array}$ \\
\hline Education level $\left(\mathrm{X}_{1}\right) \rightarrow$ Learning achievement $(\mathrm{Y})$ & 0.391 & 0.030 & $\begin{array}{l}0.421 \\
\text { Years }\end{array}$ \\
\hline of work $\left(\mathrm{X}_{2}\right) \rightarrow$ Learning achievement $(\mathrm{Y})$ & 0.229 & 0.026 & 0.255 \\
\hline Work motivation $\left(\mathrm{X}_{3}\right) \rightarrow$ Learning achievement $(\mathrm{Y})$ & 0.149 & 0.022 & 0.172 \\
\hline work discipline $\left(\mathrm{X}_{4}\right) \rightarrow$ Learning achievement $(\mathrm{Y})$ & 0.156 & 0.032 & 0.189 \\
\hline
\end{tabular}

Based on the description above, their respective total effect of the independent variable is level of education by $42.1 \%$, years of service by $25.5 \%$, work motivation by $17.2 \%$, and work discipline by $18.9 \%$. In whole, the results of the path analysis test are presented in Figure 1. 


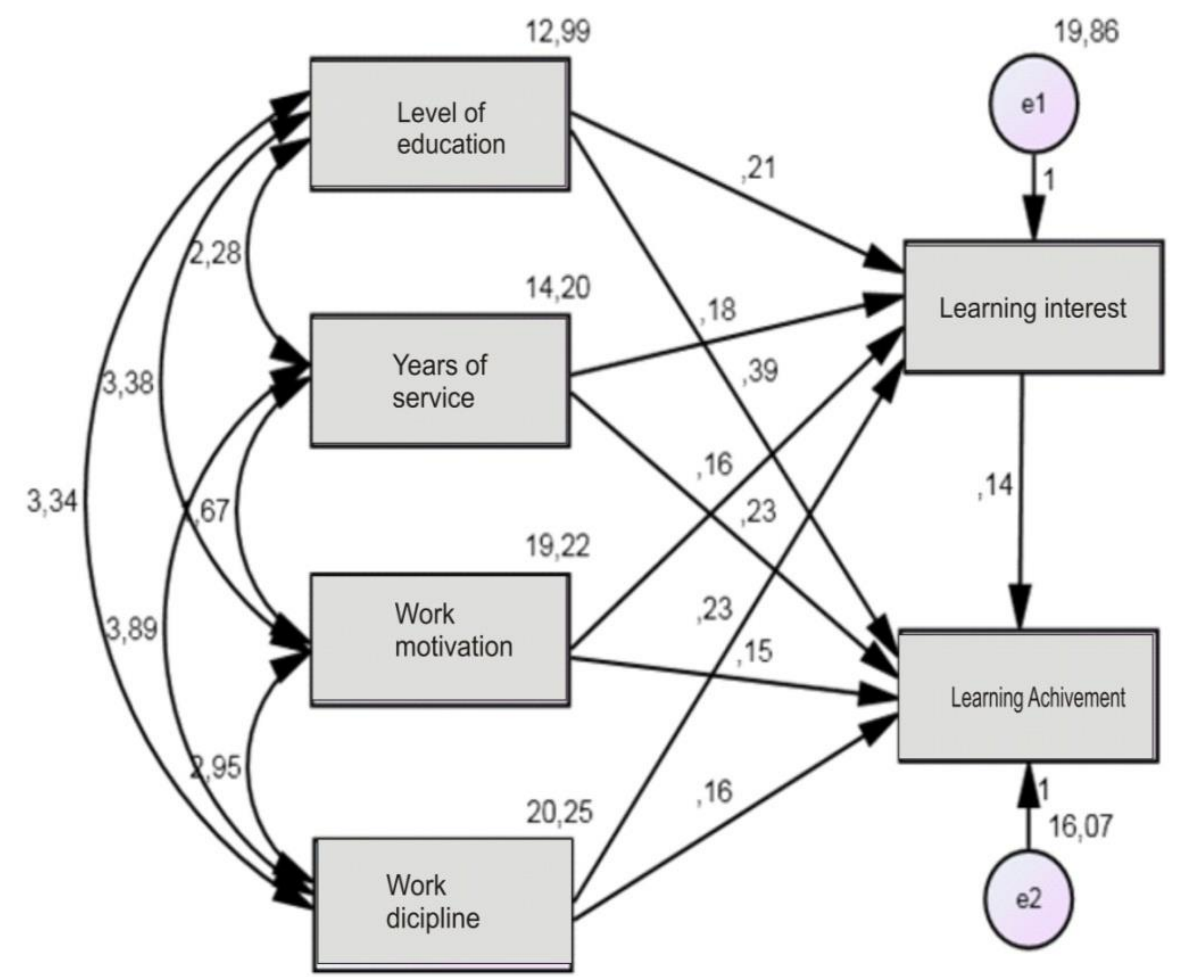

Figure 1

Path coefficient of direct and indirect effect

\section{DISCUSSION}

Education has a positive and significant effect on learning interest. This means that items in education level affect learning interest. Teachers as the spearhead of education directly seeks to affect, foster, and develop students' abilities to become intelligent, skilled and highly moral people. As the spearhead, a teacher in carrying out his duties is demanded to truly be able to master the competencies that are reflected in the ten teacher competencies which are the basic abilities that an educator or teacher must have. Mastery of teachers in combining several learning models obtained from some literature will improve students' learning achievements (Putra \& Masruri, 2018).

Years of service has a positive and significant effect on learning interest. This means that items during the years of service affect learning interest. Teachers have a very big role in school management. The years of service is a very important factor in carrying out class management tasks because, by the years of service, learning interest will run well. The years of service is also related to the mastery of the field of study materials. Every year, teachers will update the learning content consisting of the depth of learning content, mastery of learning media, and improvement of the quality of literature. The 
quality of literature depends heavily on the quality of the school library. Libraries should provide up-to-date literature, especially research literature. This is in accordance with the research by Griadhi et al. (2018) the quality of the library will have a positive effect on the learning achievement. Depth of content and variety of learning media will increase student motivation. Students with multiple learning styles will be accommodated by a variety of learning media.

The test results show that work motivation has a positive and significant effect on learning interest. This means that the items in work motivation affect learning interest. A teacher with high work motivation will tend to have higher performance, which will affect the students he teaches. This will surely lead to the growth of learning interest in students. When associated with a situation in human life that is developing, high work motivation will be used as an absolute requirement, which is grown in life because it will open views and attitudes to humans to highly value hard and sincere work, so that it can erode the unserious attitude of work. According to Turk and Vignjević (2016), the mechanisms and methods of improvement can and should be clearly defined and identified.

Work discipline has a positive and significant effect on learning interest. This means that items in work discipline affect learning interest. Teachers who carry out the teaching and learning process with high discipline will tend to be more productive. Discipline in learning related to the duration of learning in the classroom, close monitoring of student behavior, the number of teacher attendance in the classroom, and the diversity of learning media. Students will see disciplined teachers as role models in life. In addition, students' learning motivation will also increase. Discipline in applying all learning rules will support the achievement of learning objectives and improve student learning achievement.

This study found that education level has a positive and significant effect on learning achievement. This means that items in the education level affect learning achievement. Education is very important for every human being. The absence of education will make humans not able to get or have knowledge. Education mainly starts in the family; indeed, it is the first place to provide education to their children. From a family, children get guidance from personality or behavior carried out by the children to academic achievement. Teachers with higher education will have wider and quality literature. This is because the teacher's ability is strongly influenced by changes in the way of thinking when the teacher is studying in college. The change was obtained from discussions with lecturers and with friends from various backgrounds in college. Education is an indicator of a person's levels skill or productivity (Benson et al., 2004) and is often used as a prerequisite for making decisions.

Years of service has a positive and significant effect on learning achievement. This means that items in the years of service affect learning achievement. The teacher is the most important component in student's achievement. In fact, it is the teacher who is gathering with students every day in the teaching and learning process. Learning achievement is also affected by work motivation. This means that the items in work 
motivation affect learning achievement. This spotlight focuses on the teacher's inability in the learning process which has an impact on the quality of education. If the spotlight is aimed at teacher weaknesses, it is not entirely a burden because there may be an influencing system. Teacher's work motivation will promote quality education.

Work discipline has a positive and significant effect on learning achievement. This means that items in work discipline affect learning achievement. Work discipline for a teacher is expected to generate students' learning interest. Students will show interest in learning supported by a comfortable learning atmosphere. Learning achievements on cognitive aspects are strongly influenced by teacher discipline in improving knowledge related to the field of science. increase knowledge obtained from independent learning teachers, teachers attending learning workshops, teachers improving the quality of literature. With high work discipline, teachers will be able to help generate students' learning interest and will ultimately increase achievement (Luthan, 2009). Learning interest has a significant positive effect on learning achievement. Learning interest is measured in learning activities in class which is assessed by students including opening lessons, explaining lessons, mastery in teaching materials, mastery in learning methods, skills in using media, questioning skills to students, behavior during learning, assessment of learning, and closing the lesson.

Education level affects learning achievement mediated by learning interest. This shows that learning interest is able to mediate the effect of education level on learning achievement. Teachers with a high educational background will affect the level of understanding of the importance of education for children, so that they will create a learning atmosphere that is conducive to children's learning activities to encourage them to be involved in learning. Their learning interest will help them achieve maximum achievement. Teachers with high educational background will be able to improve students' achievement because they are motivated, and theirlearning interest will exist.Without learning, students will not be able to get maximum achievement (Zghidi and Loumi, 2016).

Years of service affects learning achievement mediated by learning interest. This shows that learning interest is able to mediate the effect of years of service on learning achievement. Work motivation affects learning achievement mediated by learning interest. This shows that learning interest is able to mediate the effect of work motivation on learning achievement. Teacher's high work motivation is essentially an absolute requirementfor a teacher to provide learning in the subjects he takes. This indicates the teacher's high performance which will be a stimulant for students to always be obsessed with doing their best. Motivation and positive attitude of learning affect towards learning outcomes (Adegboyega, 2018; Tasgin \& Coskun, 2018). Therefore, teachers must always increase their work motivation through learning and taking lessons from their teaching experiences.The more they know, the more they can give to students.

Work discipline affects learning achievement mediated by learning interest. This shows that learning interest is able to mediate the effect of work discipline on learning 
achievement. These findings confirm that work discipline is an activity carried out by the attitudes and behavior of students to comply with and respect the applicable provisions both written and unwritten and can receive sanctions for violations committed. Discipline is very important in order to create eligible rules so that students carry out the tasks assigned to them for the achievement of goals. Indeed, discipline manifests an attitude that reflects adherence to existing rules. According to Byars-Rue (2004), discipline should be seen as a learning opportunity for students and as a tool to increase productivity and human relations. Discipline must be seen as a learning opportunity for employees and as a tool to increase productivity and its relationship with humans, which means that employees who have high discipline in the learning process will easily increase their achievement.

\section{CONCLUSION}

This study was conducted on 200 tutors of Packet C Study Group in Jember Regency to study and analyze the factors affecting learning achievement, either directly or indirectly. The results showed that the variables of education level, years of service, work motivation, and work discipline have a positive and significant effect directly on learning interest and learning achievement. Indirectly, learning interest is able to mediate the influence of the variables of education level, years of service, work motivation, and work discipline on learning achievement. The limitation in this study is that this research was conducted on the tutors of Packet C Study Group that is equal with Senior High School level and has not been carried out to the other study groups. Further research needs to examine the relationship between technological mastery and learning achievements to measure the achievement of curriculum objectives.

\section{REFERENCES}

Adegboyega, L. O. (2018). Influence of achievement motivation on nigerian undergraduates' attitude towards examination. International Journal of Instruction, 11(1), 77-88. doi:10.12973/iji.2018.1116a.

Adejumobi, FT, and RK Ojikutu. (2013). School climate and teacher job performance in Lagos State Nigeria. Discourse Journal of Educational Research, 1(2), 26-36.

Ajzen, I. (1991). The Theory of Planned Behavior.The Organizational Behavior and Human Decision Processes , 50, 179-211.

Allameh, SM, AS Barzoki, S. Ghazinour, SA Khodaei and M. Abolghasemian. (2014). Analyzing the effect of Employee Engagement on job performance in Isfahan Gas Company. International Journal of Management Academy, 2(4), 20-26.

Anantadjaya, S., \& Nawangwulan, I. (2020). Lecturers' Competencies: A Qualitatives Study in Higher Education. Basic and Applied Education Research Journal, 1(1), 17. 
Backfisch, I., Lachner, A., Stürmer, K., \& Scheiter, K. (2021). Variability of teachers' technology integration in the classroom: A matter of utility! Computers and Education, 166 doi:10.1016/j.compedu.2021.104159.

Baron, RM and DA Kenny. (1986). The Moderator Mediator variable distinction in Social Psychological research: Conceptual, strategic and statistical considerations. Journal of Personality and Social Psychology, 51, 1173-1182.

Becker, B., M. Huselid, and D. Ulrich. (2001). The HR Scorecard: Linking People, Strategy, and Performance. Boston: Harvard Business School Press.

Benson, GS, D. Finegold dan SA Mohrman. (2004). You paid for the skills, now keep them: Tuition reimbursement and voluntary turnover. Academy of Management Journal, 47(1), 315-331.

Byars-Rue. (2004). Human Resource Management. New York: McGraw-Hill Companies.

Carter, RS and RA Wojtkiewicz. (2000). Parents involvement with adolescents education: Do daughters or sons get more help Adolescence". British Journal of Sociology of Education, 18(2), 187-199.

Carter, S. and E. Shaw. (2006). Women's business ownership: Recent research and policy developments. UK: Small Business Service.

Citriadin, Y., Wiyono, B. B., Huda, M., \& Arifin, I. (2019). The influences of teacher performance in public high schools in indonesia. International Journal of Innovation, Creativity and Change, 9(6), 25-41.

Crow, A. and LD Crow. (1992). Educational Psychology. New Jersey: Littlefield Adams and Co.

Dessler, Garry. (2010). Human Resources Management. 10 ${ }^{\text {th }}$ Edition. McGraw-Hill Companies.

Diab, SM dan MT Ajlouni. (2012). The Influence of Training on Employee Performance, Emotional Intelligence and Quality of Medical Services at Jordanian Private Hospitals. Interdisciplinary Journal of Contemporary Research in Business, 4(6), 117-127.

de la Torre, F. U. (2020). Teacher performance in civic and ethical formation: Empirical study and educational policy recommendations for junior high school in mexico. [Desempenho docente na formação cívica e ética: Estudo empírico e recomendações de políticas educacionais para méxico; Desempeño docente en formación cívica y ética:

Elacqua, G., Munevar, I., Sanchez, F., \& Santos, H. (2021). The impact of decentralized decision-making on student outcomes and teacher quality: Evidence from colombia. World Development, 141 doi:10.1016/j.worlddev.2020.105378. 
Estudio empírico y recomendaciones de política educativa para el nivel secundaria en méxico] Education Policy Analysis Archives, 28(188), 1-29. doi:10.14507/epaa.28.5255

Ekpe, I. and N. Mat. (2012). The moderating effect of social environment on the relationship between entrepreneurial orientations and entrepreneurial intentions of female students at Nigerian Universities. International Journal of Management Sciences and Business Research, 1(4), 1-16.

Fenster, DE (2014). Implications of Teacher Years of service on Teacher Quality and Student Performance in North Carolina.Thesis. North Carolina: Duke University Durham.

Gatewood, EJ, CG Brush, NM Carter, PG Greene, and MM Hart. (2004). Women entrepreneurs, growth and implications for the classroom. USA: Coleman Foundation whitepaper series for the USA Association for Small Business and Entrepreneurship.

Griadhi, M. H. W., Suarni, N. K., Marhaeni, A. A. I. N., \& Sutajaya, I. M. (2018). The effect of library services quality towards achievement motivation and learning achievement of undiksha students on bali-indonesia. Library Philosophy and Practice.

Hair, J. F., William, C. B., Barry, J. B., \& Rolph, E. A. (2010). Multivariate data analysis. New Jersey: Pearson.

Houtenville, AJ \& Conway, KS (2007). Parental Effort, School Resources and Student Achievement.The Journal of Human resources, 43(2), 437-453.

Ibru, C. 2009. Growing microfinance through new technologies.Federal University of Technology, Akure, Nigeria.

Ikhsan, F.., Kurnianto, F.., Apriyanto, B., \& Nurdin, E.. (2017). Efforts To Improve The Competency of Professionalism Teacher In Jember Regency. Geosfera Indonesia, 1(1), 16-21. doi:10.19184/geosi.v1i1.6191.

Kawuryan, S. P., Sayuti, S. A., Aman, \& Dwiningrum, S. I. A. (2021). Teachers quality and educational equality achievements in indonesia. International Journal of Instruction, 14(2), 811-830. doi:10.29333/iji.2021.14245a.

Khan. (2010). Effects of Human Resource Management Practices on Organizational Performance an Empirical Study of Oil and Gas Industry in Pakistan. European Journal of Economics, Finance and Administrative Sciences, 24(6), 157-174.

Kraaykamp, G. (2000). Ouderlijk gezin en schoolsucces.Journal Tijdschrift voor Onderwijsresearch. 2(5): 179-194.

Luthans, F. (2009). Organizational Behavior. $12^{\text {th }}$ Edition, New York: McGraw-Hill Inc.

Manzoor, QA (2011). Impact of employees motivation on organizational effectiveness. European Journal of Business and Management, 3(3), 36-44. 
Marisa, S. dan A. Sonia. (2005). Linking organizational resources and work engagement to employee performance and customer loyalty: The Mediation of Service Climate. Journal of Applied Psychology, 90(6), 1217-1227.

Muola, JM (2010). A Study of the Relationship between Academic Achievement Motivation and Home Environment among Standard Eight Pupils in Machakos.Educational Research and Reviews, 5(5), 213-217.

Mutiarawati, A. (2021). Implementation of School-Based Management in Improving the Quality of Learning in the City of Bekasi. Basic and Applied Education Research Journal, 2(2), 78-87.

Obicci, PA (2015). Effects of spirit at work leader on employee performance in Uganda. Net Journal of Business Management, 3(1), 1-12.

Phillips, E. (2009). The Effect of Years of service on Teacher Performance in Secondary Education. Thesis.Policy Analysis and Management Honors.

Putra, U., \& Masruri, M. (2019). The Effectiveness Comparison Between Inquiry and Problem Based Learning Towards Geography Learning Outcomes. Geosfera Indonesia, 4(2), 146-163. doi:10.19184/geosi.v4i2.10849.

Ritiauw, SP (2011).Kualifikasi, Kompetensi Dan Sertifikasi Sebagai Jaminan Mutu Guru Profesional. Diakses pada tanggal 11 Februari 2021 dari situs:http://historyamagistravitae.blogspot.com/2011/03/kualifikasi-kompeteteni-dan sertifikasi.html? $\mathrm{m}=1$.

Salman, A. (2009). How to start a business: A guide for women. Pakistan: Center for International Private Enterprise, Institute of National Endowment for Democracy, affiliate of the USA Chamber of Commerce.

Shane, S. (2003). A general theory of entrepreneurship: The individual-opportunity nexus. UK: Edward Elgar.

Silvia, PJ (2001). Interest and interests: The psychology of constructive capriciousness. Review of General Psychology, 5(1), 270-290.

Simba, NO, JO Agak and EK Kabuka. (2016). Impact of Discipline on Academic Performance of Pupils in Public Primary Schools in Muhoroni Sub-County, Kenya. Journal of Education and Practice, 7(6), 164-173.

Tasgin, A., \& Coskun, G. (2018). The relationship between academic motivations and university students' attitudes towards learning. International Journal of Instruction, 11(4), 935-950. doi:10.12973/iji.2018.11459a.

Tsui, Ming. (2005). Family income, home environment, parenting, and mathematics achievement of children in China and United States. Journal Education and Urban Society, 2005(37), 336. Diambil pada tanggal 26 April 2013 dari http://eus.sagepub.com/content/37/3/336 
Turk, M. and B. Vignjević. 2016.Teachers' Work Ethic: Croatian Students' Perspective.Foro de Educación, 14(20), 489-514.

Van Vugt, M. (2006). Evolutionary origins of leadership and followership.Personality \& Social Psychology Review, 10(4), 354-371.

Wright, P., Gardner, T., Moynihan, L. and Allen, M. (2005). The relationship between $H R$ practices and firm performance: Examining casual order (CAHRS Working Paper \#04-06). Ithaca, NY: Cornell University, School of Industrial and Labor Relations, Center for Advanced Human Resource Studies.

Zameer, H., S. Ali, W. Nisar, M. Amir. (2014). The impact of the spirit at work on the employee performance in beverage industry of Pakistan. International Journal of Academic Research in Accounting, Finance and Management Science, 4(1), 293-298.

Zghidi, N. and A. Loumi. (2016). The Sense of Competence, A Moderator between Motivation and Academic Performance in Physical Education: An Application by the Principal Component Analysis. International Journal of Physical Education, Sports and Health, 3(5), 316-322. 